Article

\title{
Funding Sustainable Online News: Sources of Revenue in Digital-Native and Traditional Media in Spain
}

\author{
Alfonso Vara-Miguel ${ }^{1}$ (D), Cristina Sánchez-Blanco ${ }^{1}$, Charo Sádaba Chalezquer ${ }^{1}$ (D) and Samuel Negredo ${ }^{2, *}$ (D) \\ 1 Department of Marketing and Media Management, School of Communication, Universidad de Navarra, \\ 31009 Pamplona, Navarra, Spain; avara@unav.es (A.V.-M.); csblanco@unav.es (C.S.-B.); \\ csadaba@unav.es (C.S.C.) \\ 2 Department of Journalism, School of Communication, Universidad de Navarra, 31009 Pamplona, Navarra, Spain \\ * Correspondence: negredo@unav.es
}

Citation: Vara-Miguel, A.;

Sánchez-Blanco, C.; Sádaba Chalezquer,

C.; Negredo, S. Funding Sustainable

Online News: Sources of Revenue in Digital-Native and Traditional Media in Spain. Sustainability 2021, 13, 11328 https://doi.org/10.3390/su132011328

Academic Editor: Mark Anthony Camilleri

Received: 31 August 2021

Accepted: 8 October 2021

Published: 14 October 2021

Publisher's Note: MDPI stays neutral with regard to jurisdictional claims in published maps and institutional affiliations.

Copyright: (c) 2021 by the authors. Licensee MDPI, Basel, Switzerland. This article is an open access article distributed under the terms and conditions of the Creative Commons Attribution (CC BY) license (https:/ / creativecommons.org/licenses/by/ $4.0 /)$.

\begin{abstract}
Digital news publishers strive to balance revenue streams in their business models: as standard advertising declines, alternatives for sustaining digital journalism arise in the forms of sponsored content, user donations and payments-one-off purchases, subscriptions or memberships, public or private grants, electronic commerce, events and consulting. An exhaustive study found 2874 active online news publications in Spain, and it observed the adoption of such models in early 2021. Advertising remains the most popular source of income for digital news operations (85.8\%) and most sites rely on just one or two revenue streams (74.5\%). We compare the cases in our census by their origin (digital-native or non-native), geography (local/regional or national/global) and topic scope (generalist or specialized). We find that traditional, national and specialized online media have a broader and more innovative revenue mix than digital-native, regional or local and general-interest news outlets. The comprehensiveness of this pioneering study sheds light for the first time on the risk that the lack of diversification and innovation in funding sources may imperil the financial sustainability of some online news operations in Spain, mostly those with a smaller scope and no backing from a traditional business, according to the results we present here.
\end{abstract}

Keywords: media economics; digital economy; revenue streams; digital-native media; news websites; digital publishing; news organizations; paywall; crowdfunding

\section{Introduction}

Digitization and the internet have transformed the funding model of online news organizations, which used to be based almost exclusively on advertising. Media companies have conceived and implemented new revenue streams, and they have focused their efforts on developing models for users to pay for digital news and editorial content [1].

This new environment multiplies the supply of editorial content from news publishers to readers and users. First, the market evolves from a scarcity situation into a market of abundance, where most news stories become low-value commodities, in economic terms [2], and most consumers are satisfied with the free news available online from broadcast and cable brands or other digital sources [3]. Secondly, although most of the audience is using several devices to get digital news [4,5], mobile devices are becoming the main platform for news consumption [5], and they are creating additional readership among those who do not use legacy brands [6,7]. New platforms such as social media emerge as alternatives to traditional digital publishing and broadcasting on media organizations' own platforms; this tendency towards off-site consumption of content takes monetization options away from the hands of media companies and subjects them to new intermediaries. Therefore, the new digital revenue does not make up for the losses in sales of print editions [8]. Finally, and to introduce a specific angle of our work, new digital-native editorial sites are launched, both by incumbent and emerging publishing companies of all sizes. This represents more competition in an already complex market [1]. 
There are no universal recipes, nor a single way for digital journalism to succeed and be sustainable, but there are some lessons to learn from experience in the last decades. First of all, there are more opportunities to survive and succeed if multiple sources of revenue are involved, and therefore the organization is not dependent only on a handful of private or public advertisers or sponsors, or any other single kind of income [9]. Second, the odds are better for the publisher if contents stand out as different and if they are oriented towards the needs of the public: aligning producers and consumers is central to commercial success, but studies have shown that journalists and news consumers differ significantly about what news is of interest $[1,10]$. We have investigated this in terms of the geographical reach of publications and their editorial scope (general interest or specialized on a certain topic or subject area). Third, innovation provides a competitive advantage regarding not only the editorial product and the services that constitute the editorial proposition for the user, but also how it is designed as a business and how it will be funded.

The COVID-19 health crisis has accelerated some practices that were already in use or in development for the transformation of how news organizations fund their activities, as a consequence of the challenges of digital transformation, the fall of advertising revenue and therefore the need to innovate, in the whole value chain, in order to ensure their financial sustainability [2,11].

Looking at recent developments, following the global Digital News Report 2021, "the last year has also seen more quality journalism go behind paywalls, as print and digitalborn publishers turn to subscription, membership, and donations to reduce their reliance on advertising-which online continues to go primarily to Google and Facebook" [5] (p. 14). Specifically, in Spain, 2020 was a year when many of the largest news organizations, newspapers and digital-native sites alike, started charging for their digital news, with relative success [12]. This measure can be understood in the face of the abrupt fall in print sales and in advertising revenue $[13,14]$.

Lambrecht et al. [15] propose three sources of online revenue for media companies: a company may sell content, sell customer information and sell advertising space, considering the exchange of a digital good in the face of which consumers may offer their money, their information and their time or attention. Specifically, in the media field, Bekh states that "a revenue model describes the structure of how a company generates revenue or income. It is just a component of the business model" [16] (p. 548). Among the most popular revenue models of digital media are the following: advertising, affiliate marketing and sales, subscription, freemium, one-time purchase and pay-per-use [17].

In general, publishers have preferred a mix of multiple sources of revenue instead of strong dependency on a single source. However, the choice between advertisements and paid content seemed more like a dilemma because increased advertising used to be associated with lower revenue through pay $[15,18]$. The strategy to increase income involves trades-offs between sales revenues and ad revenues. Paid news drives content sales revenues, and free news drives traffic and increases advertising sales: "Producing the highest possible revenue for a news enterprise may result from content sales, advertising sales, or a combination of the two" [1] (p. 150). In this sense, it is necessary that media managers work coherently to obtain revenue from sources that will be sustainable over time.

\section{Main Sources of Revenue at Media Firms}

In this research, the sources of revenue of Spanish digital media have been classified considering the criterion of the lucrative aim of the funds: commercial or non-commercial. Firstly, the main sources of commercial funding are marketers/advertisers, consumers or investors and take the form of standard advertising; sponsored content; paying for news, subscriptions or memberships; and electronic commerce.

Standard advertising. According to Cerezo, "understanding the transformation of digital advertising is fundamental for making the future of online media sustainable" [19] (p. 30). It is still the funding source most widely used by the media, despite being ques- 
tioned and forced to evolve because of ad blockers and technological developments [20,21]. In this sense, we find some of the most important environmental forces that are changing the way in which advertising operates: the competitive and economic environment: proliferation of media and clutter; the technological environment: the rise of digital media, programmatic advertising, big data and data management platforms and customized communication, artificial intelligence; the legal/regulatory environment: privacy regulation (e.g., GDPA, CCPA), nutritional labeling laws and warning laws; and the consumer/social environment: attitudes towards privacy, importance of corporate social responsibility, growing concern about environment [22].

It is necessary to propose an advertising model which is good for consumers, useful and non-intrusive, as well as beneficial for advertisers and the media [23]. "Business models should be understood as a specific ecosystem for each title and each market, where the advertising model is part of the diversification strategy and where synergies are enhanced" [19] (p. 39).

Sponsored content. In the face of the current state of advertising, more integrated and less intrusive forms of sponsorship grow as a way to sustain online news organizations financially $[24,25]$. Although branded content is not the main source of revenue, media organizations have increased their resources and commercial propositions in this format recently [26]. Native advertising deserves a special mention. By this, we mean paid messages which are embedded in digital environments and are hardly distinguishable from the editorial context that surrounds them. When they appear, usually under the label of "sponsored content" or "partner content", they come in the form of articles or other kinds of content $[27,28]$, and therefore there is "format similarity" because advertising emulates editorial content [29]. Publishers are becoming distributors and producers of advertising, on top of their traditional role as content creators [24], and this entails a risk for them to lose credibility, be them native or non-native media [30], and there is serious debate among journalists because not all of them agree with the model [31,32]. Native advertising expenditure in Spain had interannual growth, up to $26.9 \%$, from 2019 to 2020 [14]. Despite the differences, for this article's purposes, native advertising and sponsored content were considered a similar phenomenon.

Paying for news, subscriptions, memberships. Direct payment by users for access to news and editorial content online has become widespread as publishers put up a variety of subscription models on their sites [33,34]. The most frequent type of payment is the paywall, a subscription model which limits access to all digital news (hard paywall) or some specific news (soft paywall). This second type takes the form of the metered model, which lets the public read a specific amount of news without paying, or the freemium model, which allows free access to a specific news chosen by news editors, but charges for valuable content. Besides, memberships are a type of direct payment made by individuals to support a media brand with whom people share a common political, social view or interest. In memberships, the concept of consideration (pay for content) is more diluted than in paywalls, because there is a strong sense of community or identity behind the payment.

Regardless of the specific type of payment, nowadays the media look not only to attract new paying readers but also to keep them loyal and to reduce the churn rate [35] by presenting their value proposition attractively [36]. In fact, several studies demonstrate that users are more willing to subscribe to a media organization when it provides them with useful and valuable content [37-39]. Publishers work on bundling and unbundling strategies to address the ever-increasing user demands [40].

Electronic commerce. Selling products to readers is not a novelty for media companies. The practice has evolved from selling products to subscribers, to affiliate marketing where users were made to navigate from the publication to an external shopping site, to attribution commerce-an improved version of affiliate marketing that allows the media organization to collect user data-, to embedded e-commerce or content commerce where the media organization owns or licenses the products it sells to readers, and it can sell from 
its own site, and therefore control and manage user data [41]. These commerce-oriented revenue models are especially attractive for specialized-content media [42].

Secondly, the main alternative source to commercial funding is non-commercial or non-for-profit funding, which includes donations, grants or other type of funds from private individuals, foundations, companies, charitable trusts, NGOs and other 'third sector' organisations, but also public funding in the form of direct and indirect subsidies or grants for news publishers.

Donations and crowdfunding. This type of funding is a voluntary and occasional transfer of money from an individual or organization (donor) to a news organization (donee) in which there is no exchange of value (consideration) on the part of the media firm. In journalism, the most common types of crowdfunding are fundraising for a single news story; for continuous coverage of topics (i.e., cultural, environmental, financial); for promoting the creation of a new platform or news outlet; and for a service that supports journalism. Raising funds for a single story used to be the most frequent form of crowdfunding, but fundraising for a regular coverage is becoming increasingly common $[43,44]$. Donors' motivations to support journalism financially are usually grounded in curiosity or entertainment; in extrinsic motivations such as empathy or the feeling of being part of an organization; or in "foreign-extrinsic" motivations, linked to responsibility, or the sense of guilt $[45,46]$. This revenue stream has become a key source of income for many digital media outlets that offer the audience an independent voice on current affairs, as part of their value proposal.

Direct public subsidies or private grants. When the commercial news model is not enough to sustain media firms, public support is common across Western European countries, including Spain. These subsidies or grants are popular because they are perceived by the part of the audience as a good way to promote a far greater (idiomatic, cultural, social) diversity/plurality than a market model would support by itself. Most of the funds are directed at news organizations with low advertising revenues, dedicated to coverage of local issues in a town and/or in a specific community [47], that without the public funding would probably not survive. However, although the use of public grants or subsidies (and civil society resources) may support journalism and contribute to pluralism, they do not usually provide sufficient resources to finance sustained news organizations, and sometimes, these funds raise some concerns about media independence [48].

Besides public subsidies to the press, another non-commercial funding model is the not-for-profit pursued by some news firms, and mostly relying on grants from private foundations looking to improve their communities with the promotion of public-interest journalism (local, specialized content). Some private companies, including Google and Facebook, have set up their own funding programs to assist media companies to adapt to the new technological advances $[49,50]$.

Consulting, events and other sources. Some media companies are developing their catalog of services, offering conference programs, courses, and event organization as another source of income. Target groups for these services could differ; sometimes they address niche groups, usually when specialized media are involved, or wider targets such as the general public.

\section{Research Questions}

Our research analyzes four questions. With around 3000 news sites registered in 2018 [51], the Spanish online media market stands out for its variety and diversification in terms of size, reach, topic scope and ownership) but also for its financial weakness, which is incompatible with the long-term sustainability of media organizations as businesses and increasing job insecurity [51-53]. Furthermore, among Spanish digital media, local and regional organizations prevail (73\%); this underlines the importance of proximity in this market $[52,54,55]$. Additionally, although general news predominates in the Spanish market, there is also a broad offer of specialized sites (32\%) [51]. With this framework, we will focus our research on the streams of income used by Spanish online news organizations. 
We will quantify how many sources of revenue digital-native media use, and we will identify what kinds of sources they are. As we mentioned previously, the Spanish market may have adopted new sources, alternative to traditional advertising, although the latter is still a staple of many news organizations' income structure. Therefore, the first research question is:

Q1: Do Spanish digital media tend to combine several income sources, as part of the limited reliability of advertising and the need to diversify how they bring revenue in?

More specifically, we are interested in whether three kinds of media differ in the set of funding sources they rely on. First, between digital-native media and traditional or nonnative media. Native media are different from traditional or non-native ones in terms of business models, distribution strategies, corporate organization and editorial priorities [56]. They only operate online, and they are carving out a viable and sustainable business on the net, using new funding models [17]. Meanwhile, traditional media usually manage both offline (print or broadcast) and online platforms. Frequently, they anchor their heritage in the quality of their content and of their consumer relations [57]. For traditional brands, it is economically rational to cover news in a quality-oriented manner [58,59]. By including quality as a part of their brand identity, non-native outlets find an audience that is ready to pay money, or at least attention, for this sort of coverage [60]. Previous research shows that, in Spain, most digital-native sites have a local reach and the companies publishing them hardly reach economic profitability: 61\% had revenues below 100,000 euros, which forces them to diversify their sources of funding [54,61]. Moreover, many of those digital-native sites were launched by founders with little experience in media management [51] or by journalists laid off from mainstream media [53] lacking the knowledge and competencies to develop new revenue streams. Consequently, we can predict that digital-native media may have adapted naturally their revenue model to the funding opportunities that emerge in the new news ecosystem, unlike the more traditional revenue scheme among non-digitalnative media:

Q2: Do digital-native media use more conventional and alternative sources of revenue than traditional media?

A second aspect that we aim to analyze are differences between media with national or global reach and those covering a regional or local area. Without any intention to get into a definitional debate about terms as local journalism, community journalism, or hyperlocal journalism (see Negreira-Rey, 2020 [54] for a deeper conceptualization of local-hyperlocal digital media), we understand local-regional journalism as news produced for and about the very local or regional level across a range of media platforms, including online, radio and print. This type of journalism is among the most diverse subfields-from who owns it and produces it, to the forms it takes, its distribution, and the economic models that sustain it [62] (p. 194). The most popular funding sources used by local-regional media are advertising, which remains the major source of income for these local news providers [63], but the rapid decline in ad revenues are shifting media managers to alternative funding sources as charging for news [64]. Although local media have the advantage of offering niche content that national media do not usually cover, they have to face the limitations of being targeted to a potential small market. Consequently, although paywalls create additional digital revenues for local firms, at the current levels, they do not offer a viable funding model in the short term [8]. First, most of their promoters seek more social or civic than economic aims [55]. Second, founding teams are usually small and they rely on citizen cooperation to produce content [55]. Third, the small size of the areas they cover limits their audiences and advertisers, which forces them to diversify their revenue streams, adding models such as subscriptions, crowdfunding [52] or alliances with other companies to pursue common objectives, such as networks of local media [55] or media co-operatives [53]. Finally, the difficulty in achieving the sustainability and the civic aim of this local and regional online news outlets explains how they are the main recipients of public subsidies for publishing and production in the territories' own languages [51]. Thus, in comparison with the national media, it is to be expected that the Spanish national 
media, due to their stronger implantation in the market and the higher use of resources (financial, production and marketing), tend to use more types of funding sources than the local-regional media, whose possibilities are more limited due to their own business restrictions and the smaller size of the markets in which they operate:

Q3. In comparison with local and regional media, do media with a national or global geographic scope use more sources of revenue, both conventional and nonconventional, as their stronger corporate, financial, productive and marketing resources may suggest?

Lastly, we are interested in learning whether there are differences or not between media that provide specialized content and those who cover general news. Previous research suggests that charging for news is closely linked to dissimilar and specialized contents that, apart from having a high added value, cannot be easily imitated by competitors. On the other hand, news dealing with less specific issues is usually free [34,65]. Additionally, outlets covering more differential and exclusive information will be able to segment their audiences and their advertisers, thus obtaining advertising and sales revenues more efficiently than general news sites, whose model may remain oriented towards obtaining large audience numbers that will keep them under consideration by advertisers. Therefore, specialized media would rely more on user-based revenue streams (pay, subscriptions, memberships and donations) and electronic commerce, while advertising would remain a more important source in the general-interest media revenue mix. Considering the above, we propose two additional questions:

Q4a. Do media specializing in a subject area, instead of covering general news, have fewer types of revenue streams, because their focus allows them to segment their audiences and their advertisers better and concentrate their efforts in fewer funding sources?

Q4b. In comparison with general-interest news sites, do specialized sites, considering their higher grade of segmentation of public and advertisers, rely more on user-based revenue streams (pay, subscriptions, membership and donations) and electronic commerce?

\section{Materials and Methods}

\subsection{Mapping Digital Media}

This work is part of a project that aims to set out to create a full database of digital news media in Spain, which the research team understands to have accomplished in April 2021. The work is based on an effort conducted on previous occasions by the same team [66-68]. Each entry, one for each digital news outlet, was re-assessed (in terms of its active or inactive status) and re-coded, both for existing and for newly established variables. New entries were added based on industry news found in specialized publications and social media channels; suggestions from the whole research team were reviewed and incorporated by another researcher, and the portfolio of editorial brands of all the publishing groups that could be identified were scrutinized in order to make the database comprehensive and up-to-date.

The research team understands "digital news outlet" to be a journalistic publication with autonomous brand identity and content, established in Spanish territory or with a specific edition for Spain. All cases reported correspond to digital news media in Spain that had been updated with new editorial content at least once in the three months prior to observation. That was the requisite for an outlet to be considered "active"; otherwise, the case was classified as "inactive", and it was excluded from the results we present here.

Out of a total of 3949 news sites, the research project found 2874 active sites, and 1075 inactive sites; the latter were left out of the analysis for this article. Among the active sites, 1361 (47.36\%) were classified as digital-native, and 1513 (52.64\%) were found to be non-digital-native [69]. This key distinction between digital-native and non-native sites depends on whether they "started their core activity on the Internet from the moment when they were established, no matter if they started some kind of print or broadcast edition, simultaneously or afterwards" [68] (p. 35). 


\subsection{Categories and Variables}

The information was collected by a team of coders. Basic information that could be observed directly and reproduced from the website, such as the brand title, URL, location, or publishing group, were entered directly into the database, whereas the interpretation of variables such as platforms, podcast, topic, geographical reach and sources of income were subject to inter-coder agreement tests.

Three coders assessed the presence or absence of the variables describing sources of revenue in each entry in the database. For all variables, any indication of the presence of the revenue stream in the site's business model was to be coded as "Yes". Coders were asked to look at the sites' whole home page, including links to pages with more details about these revenue opportunities. If the organization mentioned, e.g., in advertising rates, in self-promotion messages, in corporate information about its services, a source of revenue such as advertisements or sponsored content, even if there were no active campaigns of those kinds on the home page, "Yes" was coded for their presence.

For the purpose of replicability of the study, beyond the justification of the categories that we developed in the previous section, the following paragraphs summarize the criteria stated in the codebook and applied by the coders to all the cases.

Standard advertising stands for display advertisements, including static and animated banners, video ads, pop-ups, pop-unders, interstitials and text and classified ads. This source of revenue was coded as it was present even if the advertisements looked like they were added by the publishing platform, with the media outlet not earning any money paid by the advertiser (e.g., in small sites using free or low-cost content management systems and hosting).

Sponsored content includes native advertisements and content, sections or news stories sponsored explicitly by a brand. These contents usually look like news stories or editorial features and their topic may or may not be directly related to the sponsoring brand.

Payments, subscriptions, and memberships are any one-off or periodical contribution by users to the news organization, in return for access to content or any other kind of benefit. This category includes the kinds listed below. If any of these payment types were available from the site's home page, the category was coded as present on the site.

- Paying for digital units: paying to access an article, an issue or the whole content for a single day.

- Simple subscriptions: monthly, quarterly or annual payments for access to the content (possibly including the website, an app, and/or PDF editions).

- Combined subscriptions: paying for access to the online service and for a print copy of the brand's periodical publication, be it daily, weekly, fortnightly, monthly, quarterly, biannual, annual, etc.

- Bundled subscriptions: access to news included with some other kind of payment or subscription to a different non-publishing service (telephone service, internet access, pay television, any other device, product or service).

- Membership of a community of users or readers: the user pays to be part of a community of readers; unlike subscriptions, which give users access to content in exchange for their payment, membership is a relational concept, people make a periodical economic contribution because they agree with a news organization's point of view, its ideology, its mission, and not to gain access to paywalled content, because access to the whole editorial offer remains unrestricted for non-members, under this revenue model. Paying members usually receive some benefits, such as early access to content, highlighted comments or even the ability to comment.

- Paying for print publications: the organization is also financed through the sources encompassed in this broad category if it sells other printed publications, such as books, magazines, yearbooks, special print editions, etc.

Donations are one-off or periodical payments that users make to support news organizations, without any compensation for the paying user in terms of access to restricted content or other benefits. Coders were asked to check whether the call for support fell more 
suitable under this category or the previous one, considering the aforementioned criteria, as well as the motivations we described in the previous section.

Public or private grants: the news organization may acknowledge being subsidized by grants from any government (local, regional, national, European, etc.), by showing the logo of said institution, not as part of any specific advertising campaign, but as a statement of this source of funding, such as "with support from...". Similarly, private grants are funds provided by external companies or foundations, without direct influence on the editorial treatment of the stories, neither the purpose to advertise a specific product or service; some examples of this kind of funding, as we mentioned previously, are projects supported by the Google News Initiative, or sustainable development sections in The Guardian and El País sustained by the Bill \& Melinda Gates Foundation.

Electronic commerce: this revenue stream was coded as being present on the site if non-journalistic products or services were offered for sale, no matter if they were the media organization's own merchandise or otherwise. Coders were asked to look for content or menu options labelled as "promotions", "shop", "shopping" or similar. The shopping service may be branded differently than the editorial site. This opportunity for the site to fund its operations is sometimes present in contents (articles) discussing such products or services, such as reviews, travel reports, lists with recommendations, etc.

Other sources, consulting, events: coders were asked to check whether each news organization proposed professional and business services such as consulting, audiovisual production, web design, developing branded content, etc. This information may appear if the organization presents itself as a "studio", or within the pages for advertisers, usually accessible from the homepage footer, or through the publishing house's corporate website. As for events, the company may fund itself selling tickets for arts performances, conferences, training or educational programs (courses, master's degrees), organized trips, sporting events, cultural forums ... either in person or online, with fully paid ticketing or supported by sponsorships. This category was also marked as being present on the site if coders found any other kind of revenue stream, not among those already described above.

Apart from revenue streams, other key distinctions we will draw are based on the geographic scope and topic scope of each site. The geographic scope deals with the area covered by the contents of the site. For the purpose of our analysis, we will use two large categories: local/regional, which includes hyperlocal outlets, and national, which also covers media from Spain with a global mission. The topic scope establishes two categories: general news and specialized content. Sites with general-interest news coverage and those dealing with a variety of topics were classified as general news, even if some of them may serve a local area or a certain demographic. Outlets with an identifiable focus on a topic or subject area were classified under the specialized label.

\subsection{Inter-Coder Agreement Tests}

Inter-coder agreement tests were based on a subsample of 350 brands, representative of the whole census of news websites, with a margin of error of $\pm 5 \%$ and a confidence level of $95 \%$. All cases were sorted using our internally assigned ID and the first ten sites; every one hundred were included in the subsample for the test. In the agreement test, each case was coded separately by two different trained coders, for each group of variables, some of which are not considered here. In the case of revenue streams, three coders worked independently on the test sample, coding each case separately. Later, results were compared.

After the test was completed, Cohen's Kappa coefficients of agreement were calculated for each pair of coders and each source of revenue. The formula by which Cohen's Kappa coefficients are calculated includes a correction that discounts agreements that may have been reached by chance. The results can be found in Table 1. According to the usual parameters of this statistical measurement [70], at least a good level of agreement was reached $(K \geq 0.6)$ in all cases but one, where the "good" threshold was not met just by 
0.01. Five out of 21 pairings reached a Kappa coefficient larger than 0.8 , which places them within the parameters of a "very good" level of agreement.

Table 1. Cohen's Kappa coefficient of agreement for each pair of coders and each source of revenue.

\begin{tabular}{cccc}
\hline Type of Sources of Revenue & Coders A-B & Coders A-C & Coders B-C \\
Standard advertising & 0.77 & 0.76 & 0.65 \\
Sponsored content & 0.70 & 0.75 & 0.75 \\
Pay, subscriptions, memberships & 0.76 & 0.85 & 0.78 \\
Donations & 0.9 & 0.92 & 0.89 \\
Public or private grants & 0.59 & 0.85 & 0.63 \\
Electronic commerce & 0.75 & 0.79 & 0.78 \\
Consulting, events and other & 0.77 & 0.83 & 0.79 \\
\hline
\end{tabular}

In any case, all discrepancies were solved by assigning a definitive category after discussion and agreement between the coders. They also formulated suggestions and specifications which were then incorporated into the codebook. Finally, the full database of sites was coded. The remaining list of cases was evenly distributed among the three different coders.

\section{Results}

Regarding the first research question (Q1), results (Table 2) show that the majority of Spanish digital media $(74.5 \%)$ use one or two revenue streams. It also brought to our attention that $10.3 \%$ of Spanish news organizations do not have any source of revenue.

Table 2. Number of sources of revenue.

\begin{tabular}{ccc}
\hline Number of Sources of Revenue & Frequency & Percentage \\
\hline None & 296 & 10.3 \\
One or two & 2140 & 74.5 \\
Three or more & 438 & 15.2 \\
Total & 2874 & 100 \\
\hline Source: authors' own elaboration with data from the Diginativemedia 2019-2021 project database.
\end{tabular}

Source: authors' own elaboration with data from the Diginativemedia 2019-2021 project database.

In relation to the types of funding (Table 3), conventional advertising is still the most widely used source of revenue by Spanish digital media, both in conventional display formats $(85.8 \%)$ and in the new kinds we identify as sponsored content $(16.4 \%)$. Nevertheless, some sites in this market have opened up to new income streams, mostly user-based funding models, either paid content, subscriptions and memberships (16.2\%) or donations (3\%). Finally, direct public subsidies or private grants are used by $13.8 \%$ of Spanish digital media.

Table 3. Types of sources of revenue.

\begin{tabular}{ccc}
\hline Type of Sources of Revenue & Frequency & Percentage $^{\mathbf{1}}$ \\
\hline Conventional advertising & 2445 & 85.8 \\
Sponsored content & 467 & 16.4 \\
Pay, subscriptions, memberships & 461 & 16.2 \\
Donations & 86 & 3 \\
Public or private grants & 392 & 13.8 \\
Electronic commerce & 337 & 11.8 \\
Consulting, events and other & 144 & 5.1 \\
\hline Total & 2874 &
\end{tabular}

1 The sum is more than 100 because sources of revenue are not mutually exclusive. Source: authors' own elaboration with data from the Diginativemedia 2019-2021 project database.

The three following research questions analyze the similarities and the differences there may be in the number (Table 4) and in the kinds of revenue streams (Table 5) used by digital media companies, which we classify according to three criteria: type of digital 
outlet (non-native vs. digital native), geographic scope (local/regional vs. national/global), and topic scope (general vs. specialized).

Table 4. Number of sources of revenue by media outlet type, geographic scope and topic scope.

\begin{tabular}{|c|c|c|c|c|c|c|c|}
\hline \multirow[b]{2}{*}{ Number of Sources } & \multicolumn{2}{|c|}{ Media Outlet Type } & \multicolumn{2}{|c|}{ Geographic Scope } & \multicolumn{3}{|c|}{ Topic Scope } \\
\hline & Non-Native & Digital-Native & Local/Regional & National/Global & Specialized & General & Total \\
\hline \multirow[t]{2}{*}{ None } & 190 & 106 & 222 & 74 & 142 & 154 & 296 \\
\hline & $12.6 \%$ & $7.8 \%$ & $10.9 \%$ & $8.8 \%$ & $12.5 \%$ & $8.9 \%$ & $10.3 \%$ \\
\hline \multirow[t]{2}{*}{ One or two } & 1046 & 1094 & 1550 & 590 & 800 & 1340 & 2140 \\
\hline & $69.1 \%$ & $80.4 \%$ & $76.4 \%$ & $69.8 \%$ & $70.3 \%$ & $77.2 \%$ & $74.5 \%$ \\
\hline \multirow[t]{2}{*}{ Three or more } & 277 & 161 & 257 & 181 & 196 & 242 & 438 \\
\hline & $18.3 \%$ & $11.8 \%$ & $12.7 \%$ & $21.4 \%$ & $17.2 \%$ & $13.9 \%$ & $15.2 \%$ \\
\hline \multirow{2}{*}{ Total } & 1513 & 1361 & 2029 & 845 & 1138 & 1736 & 2874 \\
\hline & $100 \%$ & $100 \%$ & $100 \%$ & $100 \%$ & $100 \%$ & $100 \%$ & $100 \%$ \\
\hline
\end{tabular}

Source: authors' own elaboration with data from the Diginativemedia 2019-2021 project database.

Table 5. Source of revenue by media outlet type, geographic scope and topic scope.

\begin{tabular}{|c|c|c|c|c|c|c|c|}
\hline \multirow[b]{2}{*}{ Source of Revenue } & \multicolumn{2}{|c|}{ Media Outlet Type } & \multicolumn{2}{|c|}{ Geographic Scope } & \multicolumn{3}{|c|}{ Topic Scope } \\
\hline & Non-Native & Digital-Native & Local/Regional & National/Global & Specialized & General & Total \\
\hline \multirow{2}{*}{ Conventional advertising } & 1233 & 1212 & 1723 & 722 & 913 & 1532 & 2445 \\
\hline & $82.1 \%$ & $89.9 \%$ & $85.5 \%$ & $86.7 \%$ & $81.3 \%$ & $88.8 \%$ & $85.8 \%$ \\
\hline \multirow{2}{*}{ Sponsored content } & 257 & 210 & 289 & 178 & 181 & 286 & 467 \\
\hline & $17.1 \%$ & $15.6 \%$ & $14.3 \%$ & $21.4 \%$ & $16.1 \%$ & $16.6 \%$ & $16.4 \%$ \\
\hline \multirow{2}{*}{ Pay, subscriptions, memberships } & 357 & 104 & 250 & 211 & 244 & 217 & 461 \\
\hline & $23.8 \%$ & $7.7 \%$ & $12.4 \%$ & $25.3 \%$ & $21.7 \%$ & $12.6 \%$ & $16.2 \%$ \\
\hline \multirow{2}{*}{ Donations } & 40 & 46 & 46 & 40 & 52 & 34 & 86 \\
\hline & $2.7 \%$ & $3.4 \%$ & $2.3 \%$ & $4.8 \%$ & $4.6 \%$ & $2.0 \%$ & $3.0 \%$ \\
\hline \multirow{2}{*}{ Public or private grants } & 214 & 178 & 362 & 30 & 107 & 285 & 392 \\
\hline & $14.3 \%$ & $13.2 \%$ & $18.0 \%$ & $3.6 \%$ & $9.5 \%$ & $16.5 \%$ & $13.8 \%$ \\
\hline \multirow{2}{*}{ Electronic commerce } & 211 & 126 & 172 & 165 & 169 & 168 & 337 \\
\hline & $14.1 \%$ & $9.4 \%$ & $8.5 \%$ & $19.8 \%$ & $15.0 \%$ & $9.7 \%$ & $11.8 \%$ \\
\hline
\end{tabular}

Source: authors' own elaboration with data from the Diginativemedia 2019-2021 project database.

\subsection{Native vs. Non-Native}

A chi-square test of independence was performed to examine the relation between the type of media (native vs. non-native) and the number of sources of funding used by the media. This test determines whether there is a significant association between two or more categorical variables [71]. Thus, we want to test for a relationship between the type of media (digital-native or non-native) and the number of sources used by each group. Since the $p$-value is lower than our chosen significance level, $\mathrm{X}^{2}(2, \mathrm{~N}=2874)=47.7, p<0.000$, we conclude that there is enough evidence to suggest a significant relationship between the two variables. As Table 4 shows, although there is a larger percentage of non-native media not declaring any income stream (12.6\%), digital-native media use fewer sources of revenue than non-native media. $18.3 \%$ of non-native media use three or more funding sources, as opposed to just $11.8 \%$ of digital natives with such a breadth of revenue streams.

Regarding the possible differences between the kinds of revenue streams used by each pair of kinds of media (Table 5), the chi-square tests of independence used shows some significant differences between the funding sources used by digital-native media and nonnatives. Defying our expectations, non-native media rely on advertising revenue sources $(82.1 \%)$ slightly less than digital-native sites $(89.9 \%)\left(X^{2}(1, N=2849)=35.1, p<0.000\right)$, and those traditional players use more alternative income streams than their digital-native competitors. The most pronounced differences are found in revenue types relying directly on users' financial contributions: this income stream is present in $23.8 \%$ of non-native media, whereas it is used by just $7.7 \%$ of digital-native sites $\left(X^{2}(1, N=2848)=135.2\right.$, $p<0.000)$. There are significant differences, too, in electronic commerce: $14.1 \%$ of nonnative sites are funded this way, and it is $9.4 \%$ among digital natives $\left(X^{2}(1, N=2848)=15.0\right.$, $p<0.000)$. On the contrary, there are no differences between digital-natives and nonnatives in the presence of sponsored content $\left(X^{2}(1, N=2847)=1.2, p=0.267\right)$, dona- 
tions $\left(X^{2}(1, N=2848)=1.3, p=0.243\right)$ or public or private grants $\left(X^{2}(1, N=2849)=0.6\right.$, $p=0.416)$.

\subsection{National vs. Local-Regional}

We will now present the results for the number of sources of revenue. Data show significant differences between national news organizations and local/regional ones $\left(\mathrm{X}^{2}(2, \mathrm{~N}=2874)=36.2, p<0.000\right)$. National media are more likely to use more sources of revenue than media with a narrower geographical scope. Furthermore, not only are there fewer national-scope media organizations without any identifiable revenue stream ( $8.8 \%$, slightly less than $10.9 \%$ observed among local and regional sites), but also, national media use a broader range of revenue streams than sites with a regional or local focus. Up to $21.4 \%$ of national media-including those based in Spain but with a global scope-have more than three revenue streams, against $12.7 \%$ of local and regional sites (Table 4 ).

Results about the types of sources of revenue show that, although there are no differences in the use of conventional advertising $\left(X^{2}(1, N=2849)=0.7, p=0.400\right)$, national media use a broader range of alternative revenue streams, in comparison with local and regional sites (Table 4). For instance, a larger number of national sites carry sponsored content $(25.3 \%)$ than local-regional media do $(14.3 \%)\left(X^{2}(1, N=2847)=21.7, p<0.000\right)$; more national sites receive revenues from user payments (25.3\%, as compared to $12.4 \%$ of locals-regionals) $\left(X^{2}(1, N=2848)=72.5, p<0.000\right)$, and electronic commerce is also implemented in national sites roughly double than in local and regional outlets $(19.8 \%$ for just $8.5 \%)\left(X^{2}(1, N=2848)=71.7, p<0.000\right)$. The only revenue stream that is much more used by sites with a local or regional reach are public or private grants $(18 \%$ vs. just $3.6 \%$ among nationals $)\left(X^{2}(1, \mathrm{~N}=2849)=102.3, p<0.000\right)$.

\subsection{General News vs. Specialized Sites}

Finally, we examine the differences in revenue models between general news sites and digital media outlets specializing in a subject area. Results from a chi-square test of independence show that there are significant differences between the two groups in the amount of funding methods used by each one, $\mathrm{X}^{2}(2, \mathrm{~N}=2874)=17.9, p<0.000$. There is a larger proportion of specialized sites where no revenue stream is observed $(12.5 \%$ as opposed to $8.9 \%$ among general news sites), but there are proportionally more specialist sites with three or more income sources $(17.2 \%)$ than there are general news sites with such a varied funding mix (13.9\%).

Looking at the kinds of income streams in use at each part of the market, although specialized media continue to rely on traditional advertising, they do so to a lesser extent than their general news competitors $\left(X^{2}(1, N=2849)=31.1, p<0.000\right)$. No less than $81.3 \%$ of specialized sites display conventional advertising, compared to $88.8 \%$ of general news sites. There are significant differences between both groups, too, in user-originated revenue streams. One of them is the pay, subscription or membership model, which is implemented by $21.7 \%$ of specialized digital media outlets, whereas it is found in just $12.6 \%$ of general news sites $\left(X^{2}(1, N=2848)=41.9, p<0.000\right)$. Another kind of economic contribution by users are donations: $4.6 \%$ and $2 \%$, respectively $\left(X^{2}(1, N=2848)=16.4, p<0.000\right)$. Finally, there are differences in the adoption of electronic commerce, too: it is found proportionally more in specialized media $(15 \%)$ than in general news sites $(9.7 \%)\left(X^{2}(1, N=2848)=18.3\right.$, $p<0.000)$. On the other hand, general news sites tend to use public or private grants as a source of funding $(16.5 \%)$ comparatively more than specialized editorial sites $(9.5 \%)\left(\mathrm{X}^{2}\right.$ $(1, \mathrm{~N}=2849)=28.1, p<0.000)$. The only revenue stream used similarly by both groups is sponsored content (around 16\%) $\left(\mathrm{X}^{2}(1, \mathrm{~N}=2847)=0.1, p=0.740\right)$.

\section{Discussion}

Data analysis shows that news organizations' digital funding mix is less varied than one may expect after 25 years of online news consumption [72]. Just 15\% of Spanish digital media outlets are funded through three or more revenue streams. The rest rely on just 
one or two sources of income, among which traditional advertising dominates over more innovative solutions. The comparison with previous studies such as those by Salaverría (2019), Tejedor (2020) or Negreira-Rey (2020) in the case of local and regional media (2020) shows that, in general terms, the income structure of Spanish digital media still suffers from low diversification and it evolves slowly towards new revenue models [51,52,54]. Moreover, the fact that the main source is still standard advertising, for which revenue is declining, poses serious questions about the medium-and-long-term sustainability of news publishing houses, as this source is the only one in use at the majority of the Spanish digital newspapers and non-fee-based radio and television networks.

In agreement with previous research $[11,73,74]$, the decline of conventional advertising revenue explains the adoption of new revenue streams. In spite of not having reached mainstream status in the market, these innovative funding models show that some companies in Spain — the largest ones, mostly [73] but also new alternative digital-native media [52] - have redefined and experimented with their digital business strategies. Thus, our research shows that sponsored content and user payments-per unit, by subscription or through a membership_-are the most popular new forms of digital revenue among Spanish media companies, as each was found to be used at $16 \%$ of all active online news outlets in the study. This percentage is slightly higher than what previous studies found, and subscriptions have grown especially among digital natives: in 2018 this revenue stream was used only by $4 \%$ of digital-native sites [51] and our study has observed that $7.7 \%$ have adopted it already. This increment confirms, too, the conclusions obtained by Tejedor (2020) from a sample of Spanish alternative media, whose editors highlighted the subscription as the most important way to complement the revenue obtained through advertising [52]. We wish to stress that the fact that media companies come to the market with the possibility of these new revenue streams does not ensure that potential clients and users will adopt them. For instance, data show that the strategy of user payments for access to news content, which has been recently boosted with heavy promotion by the main Spanish publishing corporations, has had a very slow effect on the strong reluctance of users in Spain towards paying for online news content. Merely $12 \%$ of users paid for digital news in 2020, and this proportion is similar to previous years [12]. Sponsored content has been adopted in Spain to an extent similar to what can be found in other countries [9], and it shows the new pressures and opportunities facing established Spanish digital media, while revenue from standard advertising continued to fall.

The third idea that the general data suggest is the use of new non-transactional formulas that benefit both non-profit and for-profit news organizations: user donations $(3 \%)$ and public or private grants $(13.8 \%)$. However, in comparison with the study by Salaverría et al. from 2018 [51], data suggests that these outlets have barely taken up donations as a revenue stream and the percentage of sites supported by institutional grants has receded (from $19.3 \%$ in 2018 to $13.8 \%$ in 2021). As we will show later, they are especially popular in Catalonia and the Basque Country. These other kinds of funding streams embody the search for alternatives to the commercial model. They look to preserve public-interest journalism by supporting minority cultural and social initiatives, usually with a local scope, which would hardly survive without these actions.

All these general ideas can be qualified when we analyze the income structure of media organizations more in depth. Our research intended to demonstrate that the mix of revenue streams is not universal and that the funding model is related to the origin of the news outlet (digital-native or non-native), to the geographic scope (local/regional vs. national) and to the topic scope (general-interest or specialized).

Data show that, contradicting the proposal in our research question, the revenue mix of Spanish digital-native media outlets is less diversified, with fewer income streams, than non-native media. In fact, just $11.8 \%$ of digital-native media are funded through three or more kinds of sources, whereas no less than $18.3 \%$ of traditional media have implemented this many revenue streams. Furthermore, the income structure is much more conventional among digital-native media, with nine out of ten relying on conventional 
advertising (89.9\%). Other potential sources of funding are scarcely used by digital-native sites: sponsored content $(15.6 \%)$, public or private grants $(13.2 \%)$, e-commerce $(9.4 \%)$, user payments $(7.7 \%)$ or donations $(3.4 \%)$. In comparison, traditional media have a more diverse funding structure, open to experimenting with new revenue streams. User payments for access to content are the kind that stands out in the online business portfolio of traditional media companies, as $23.8 \%$ of them offer some kind of single-access payment or recurring subscription or membership model. Sponsored content $(17.1 \%)$ and e-commerce $(14.1 \%)$ are popular forms of funding, too.

Among the reasons for traditional media to have a more diverse and innovative funding structure, we may pick up that they need it, they can do it, and they must do it. First, traditional media need broader sources of funding because they have suffered the financial impact of the crisis on their balance sheets more than digital-native media. Recent experience has shown Spanish media managers that the only way to survive is to be open to new funding models that could capture the value of their audiences and advertisers/marketers at least to the extent to be able to compensate for the losses in print subscriptions and advertising spend [74]. Second, they can do it because they have greater financial, productive, marketing and human resources to develop all these funding alternatives, as traditional media are usually part of large media groups [73]. Finally, they must expand their sources of funding if they want to preserve their brands as references of quality journalism. Good journalism is expensive, and the traditional revenue model is not enough to finance it [75].

These three reasons possibly explain, too, why media with a national geographic scope use more diversified and innovative sources of funding than local-regional media: up to $21.4 \%$ of national media have more than three revenue streams, against $12.7 \%$ of local and regional sites. Furthermore, they use more sponsored content $(21.4 \%)$, more payment from users $(25.3 \%)$ and more e-commerce (15\%) than local-regional media. While local companies can take advantage of their smaller size and niche content that is not being covered adequately by the mainstream [54,55], national news organizations require more financial resources if they want to differentiate their products from competitors in a national media market, which is much more aggressive and competitive than local-regional markets. On the other hand, we must emphasize the wider use of public or private grants by local-regional news organizations (18\% against $3.6 \%$ among national media). Its use is especially high in Catalonia and the Basque Country, two Spanish regions characterized by specific political and cultural identities, including the Catalan and Basque languages, that their respective governments aim to preserve and promote through public subsidies to local and regional media. In some ways, this funding model moves the intention from profit to preservation of the civic, social and cultural identity of the community [55]. As Hess and Waller suggest, in nations where the public interest role of journalism appears to be under threat due to the collapse of local commercial media, governments and philanthropic bodies have been urged to subsidize news at the very local level because of its importance to democracy and civic life [62] (p. 197). However, a public subsidies funding model requires that journalists and media managers are committed to independence, insulated from political pressures and focused on serving the public interest, not government interest.

Next, the data show significant differences in the funding structure between general news sites and digital media specialized in a specific thematic area. Contrary to what we expected $(\mathrm{Q} 4 \mathrm{a})$, the latter uses a wider range of funding sources $(17.2 \%$ use three or more) than the former $(13.9 \%)$. Although conventional advertising is still the most common funding source for the majority of specialized digital media, they show a more intensive use of revenues from users, either in the form of payment for digital content and memberships ( $21.7 \%$ against the $12.6 \%$ of general-interest media) or donations $(4.6 \%$ vs. $2.0 \%$, respectively), and from electronic commerce (15\% vs. $9.7 \%$, respectively). These data allow us to suggest that specialized media have chosen to expand their funding models towards alternative sources without renouncing traditional sources. Regarding the question of successful monetization, the data confirm the idea highlighted by previous research that 
the paywall is not a practical model, unless the media offer exclusive and differentiated niche products, with high relevance for relatively small but motivated audiences [3,58]. In this sense, some doubts arise about limiting the public's access to exclusive quality news and a plurality of opinions, and the emergence of a digital knowledge gap between those who can afford to pay for this exclusive information and those who cannot.

Finally, from a practical point of view, all the differences that we analyzed in this paper point to the need for publishers of online news media to understand funding models as a pillar that is complementary to their news operations' editorial models. Choosing a revenue stream requires publishers to ask themselves first what specific value proposition (local, national, specialized, general news) the company is offering to a certain audience, with the aim to fulfill their informational or entertainment needs. Thus, commercial revenues and user donations or institutional grants are both possible, sustainable and necessary for the survival of the majority of Spanish digital media firms. However, their use is not universal, and it depends on the nature of each news outlet (native or not), its geographical scope (national or local-regional) and the type of content offered (general-interest or specialized). Each media manager's decisions in choosing a viable and sustainable model are influenced by the outlet's editorial model and a clear understanding of the economic value of its specific content and the strength of its relationship with its audiences.

\section{Conclusions and Further Research}

This article presents the first results of the largest and most exhaustive study about revenue streams in digital news media in Spain. In comparison with earlier studies $[51,52,54,73,74]$, this paper shows that Spanish news organizations will have to be more innovative in using traditional and alternative funding sources if they do not want to perish. Moreover, we have shown that the adoption of innovative revenue streams and models is not universal, and it depends on variables such as the traditional or digitalnative origin of the news outlet, the geographic scope and the topic scope. In general, our research shows that, in Spain, digital-native, local/regional and general-interest news outlets are more conventional in their revenue models, while sites with traditional roots, with a national scope and covering specialized topics show a broader use of new funding sources, exploring alternative revenue streams without renouncing to the most popular and established ones.

A relevant aspect that should be analyzed in future research is the relationship between the type of company to which each news outlet belongs (independent firm, media group) and its funding model. Promoting new forms of financing requires resources that are not available to all media. Here a new dilemma arises; on one hand, the largest business groups dominate the advertising and subscriptions market and maybe do not seek alternative funding sources. On the other hand, developing these alternative sources requires strong financial and marketing resources and structure, which smaller media usually do not have. Taking a closer look at the relationship between the type of media company (their ownership and size) and the funding structure will help to answer it.

The fact that many media startups restrict their business to traditional revenue streams suggests that the background, the training and the motivations of the founders and managers [51-53] of these sites that aim to be sustainable should be further researched. There are opportunities, too, for specific research on each of the funding models we have explored, such as the role of marketplaces and the possible contribution of affiliate marketing to the revenue mix of small or, more likely, large media outlets. Another possible object of study is the link between the topics covered editorially by the sites and the kinds of promoted content and of merchandise they sell through electronic commerce, to the extent that users may identify conflicts of interest between the organization's journalism and the company's business.

Finally, we must acknowledge a limitation that arises from the method of data collection. As we stated in the Methodology section, coders observed each website for hints and examples of each revenue stream-advertisements, branded content, and prompts 
to subscribe, donate, advertise or purchase products or services-and for commercial information about revenue sources, such as what can be found in the site's-or its parent company's - corporate pages. Therefore, all the data and conclusions of this research were based on publicly available information, and we could not consider any revenue stream that was not visible or declared by the news outlet on their website.

Author Contributions: Conceptualization, A.V.-M., C.S.-B., C.S.C.; investigation-data collection, A.V.-M., C.S.-B., C.S.C.; data analysis, A.V.-M.; methodology-models, A.V.-M., C.S.-B.; methodology—codebook and agreement tests A.V.-M., C.S.-B., C.S.C., S.N.; writing-original draft preparation, A.V.-M., C.S.-B., S.N.; writing-review, editing and translation, A.V.-M., C.S.-B., C.S.C., S.N. All authors have read and agreed to the published version of the manuscript.

Funding: This research was developed within the project DIGINATIVEMEDIA 2019-2021: “Cibermedios nativos digitales en España: caracterización y tendencias", and thus the research and APC were funded by Ministerio de Ciencia, Innovación y Universidades (Gobierno de España) and the European Regional Development Fund, ERDF (Fondo Europeo de Desarrollo Regional, FEDER), grant number RTI2018-093346-B-C31.

Institutional Review Board Statement: Not applicable.

Informed Consent Statement: Not applicable.

Data Availability Statement: The data presented in this study is available within the article. The underlying database is not publicly available because it contains additional information on other focus areas, which is being used by other researchers in the project. The codebook is available upon reasonable request.

Acknowledgments: Principal Investigators María del Pilar Martínez-Costa and Ramón Salaverría coordinated the codebook and the coding process. Data about topic scope was coded by Pilar Sánchez García and Avelino Amoedo.

Conflicts of Interest: The authors declare no conflict of interest. The funding institutions had no role in the design of the study; in the collection, analyses, or interpretation of data; in the writing of the manuscript, or in the decision to publish the results.

\section{References}

1. Picard, R. Funding digital journalism. In The Routledge Companion to Digital Journalism Studies; Franklin, B., Elridge, S.A., Eds.; Routledge: New York, NY, USA, 2017; pp. 147-154.

2. Goyanes, M.; Vara-Miguel, A. Probabilidad de pagar por noticias digitales en España. El Prof. Inf. 2017, 26, 488-496. [CrossRef]

3. Himma-Kadakas, M.; Kõuts, R. Who is willing to pay for online journalistic content? Media Commun. 2015, 3, 106-115. [CrossRef]

4. Chyi, H.I.; Chadha, M. News on new devices. J. Pract. 2011, 6, 431-449. [CrossRef]

5. Newman, N.; Fletcher, R.; Schulz, A.; Andi, S.; Robertson, C.T.; Nielsen, R.K. Reuters Institute. Digital News Report. 2021. Available online: https://reutersinstitute.politics.ox.ac.uk/sites/default/files/2021-06/Digital_News_Report_2021_FINAL.pdf (accessed on 12 July 2021).

6. Dimmick, J.; Chen, Y.; Li, Z. Competition between the internet and traditional news media: The gratification-opportunities niche dimension. J. Media Econ. 2004, 17, 19-33. [CrossRef]

7. Van Der Wurff, R. Are news media substitutes? Gratifications, contents, and uses. J. Media Econ. 2011, 24, 139-157. [CrossRef]

8. Myllylahti, M. Newspaper paywalls-The hype and the reality. Digit. J. 2014, 2, 179-194. [CrossRef]

9. Hardy, J. Resourcing a viable digital journalism. In The Routledge Companion to Digital Journalism Studies; Franklin, B., Elridge, S.A., Eds.; Routledge: New York, NY, USA, 2017; pp. 145-165.

10. Boczkowski, P.J.; Peer, L. The choice gap: The divergent online news preferences of journalists and consumers. J. Commun. 2011, 61, 857-876. [CrossRef]

11. Palacio, L. Modelos de negocio de los medios digitales: Diversificar ingresos para financiar el periodismo. Cuad. Periodis. 2018, 36, 9-22.

12. Vara-Miguel, A. El desplome de los diarios impresos y la resistencia al pago lastran el éxito de las suscripciones digitales. In Digital News Report España 2021. Periodismo de CALIDAD y Cercanía Para Combatir la Infodemia; Amoedo, A., Vara-Miguel, A., Negredo, S., Moreno, E., Kaufmann, J., Eds.; Facultad de Comunicación, Universidad de Navarra: Pamplona, Spain, 2021. Available online: https:/ / www.digitalnewsreport.es/2021/el-desplome-de-los-diarios-impresos-y-la-resistencia-al-pagolastran-el-exito-de-las-suscripciones-digitales / (accessed on 22 August 2021).

13. PriceWaterhouseCoopers. Entertainment and Media Outlook 2020-2024. 2021. Available online: https://www.pwc.es/es/ entretenimiento-medios/assets/entertainment-media-outlook-2019-espana.pdf (accessed on 12 July 2021). 
14. Infoadex. Estudio Infoadex de la Inversión Publicitaria en España. 2021. Available online: https://www.infoadex.es/home/ wp-content/uploads/2021/02/NP-Estudio-InfoAdex-de-la-Inversi\%C3\%B3n-Publicitaria-en-Espa\%C3\%B1a-2021.pdf (accessed on 12 July 2021).

15. Lambrecht, A.; Goldfarb, A.; Bonatti, A.; Ghose, A.; Goldstein, D.G.; Lewis, R.; Rao, A.; Navdeep, S.; Yao, S. How do firms make money selling digital goods online? Mark. Lett. 2014, 25, 331-341. [CrossRef]

16. Bekh, A. Advertising-based revenue model in the digital media market. Ekon. Vjesn. 2020, 33, 547-559.

17. Cook, C.; Sirkkunen, E. What's in a niche? Exploring the business model of online journalism. J. Media Bus. Stud. 2013, 10, 63-82. [CrossRef]

18. Gundlach, H.; Hofmann, J. Preferences and willingness to pay for tablet news apps. J. Media Bus. Stud. 2017, 14, 257-281. [CrossRef]

19. Cerezo, P. El futuro de la publicidad en la financiación de los medios. Cuad. Periodis. 2018, 36, 30-39.

20. Sánchez-Blanco, C.; Sádaba, C.; Sanjurjo-Sanmartín, E. Mecanismos comportamentales como predicción del uso de ad blocking en usuarios de noticias online. Rev. Comun. 2020, 19, 231-243. [CrossRef]

21. Hootsuite. Informe Global Sobre el Entorno Digital. 2021. Available online: https://www.hootsuite.com/es/recursos/tendenciasdigitales-2021 (accessed on 14 July 2021).

22. Taylor, C.R.; Carlson, L. The future of advertising research: New directions and research needs. J. Mark. Theory Pract. 2021, 29, 51-62. [CrossRef]

23. Dahlen, M. It's time for TGA: Truly good advertising. J. Curr. Issues Res. Advert. 2021, 42, 123-131. [CrossRef]

24. Carvajal, M.; Barinagarrementeria, I. Contenido de marca en diarios españoles: Concepto, organización y retos de los periodistas implicados. Tripodos 2019, 44, 137-152. [CrossRef]

25. Watson, S.; Bell, E.; Rashidian, N.; Harts-tone, A. The Future of Advertising and Publishing; Columbia University Academic Common: New York, NY, USA, 2018. Available online: https://academiccommons.columbia.edu/doi/10.7916/D8KP9DPJ (accessed on 14 July 2021).

26. Zomeño, D.; Blay-Arráez, R. Big data e inteligencia editorial en el branded content y en los nuevos modelos de negocio de los medios. Prof. Inf. 2021, 30, 1. [CrossRef]

27. Apostol, N.-E. What is known about native advertising in editorial contexts? A descriptive literature review. J. Media Res. 2020, 13, 59-81. [CrossRef]

28. Wojdynski, B.W.; Evans, N.J. Going native: Effects of disclosure position and language on the recognition and evaluation of online native advertising. J. Advert. 2016, 45, 157-168. [CrossRef]

29. Hwang, Y.; Jeong, S.-H. Consumers' response to format characteristics in native advertising. J. Advert. Res. 2021, 61, 212-224. [CrossRef]

30. Amazeen, M.A.; Muddiman, A.R. Saving media or trading on trust? The effects of native advertising on audience perceptions of legacy and online news publishers. Digit. J. 2018, 6, 176-195. [CrossRef]

31. Schauster, E.E.; Ferrucci, P.; Neill, M.S. Native advertising is the new journalism: How deception affects social responsibility. Am. Behav. Sci. 2016, 60, 1408-1424. [CrossRef]

32. Windels, K.; Porter, L. Examining consumers' recognition of native and banner advertising on news website home pages. J. Interact. Advert. 2020, 20, 1-16. [CrossRef]

33. Arrese, A. From gratis to paywalls. J. Stud. 2015, 17, 1051-1067. [CrossRef]

34. Vara-Miguel, A.; Sanjurjo-San Martín, E.; Díaz-Espina, C. Paid news vs. free news: Evolution of the wsj.com business model from a content perspective (2010-2012). Commun. Soc. 2014, 27, 147-167. [CrossRef]

35. Wadbring, I.; Bergström, L. Audiences behind the paywall: News navigation among established versus newly added subscribers. Digit. J. 2021, 9, 319-335. [CrossRef]

36. Nechushtai, E.; Zalmanson, L. 'Stay informed', 'become an insider' or 'drive change': Repackaging newspaper subscriptions in the digital age. Journalism 2019, 22, 2035-2052. [CrossRef]

37. Chen, W.; Thorson, E. Perceived individual and societal values of news and paying for subscriptions. Journalism 2019, 22, 1296-1316. [CrossRef]

38. American Press Institute. Paths to Subscriptions: Why Recent Subscribers Chose to Pay for News. 2018. Available online: https: / www.americanpressinstitute.org/publications/reports/survey-research/paths-to-subscription/ (accessed on 3 June 2021).

39. Fletcher, R.; Nielsen, R.K. Paying for online news: A comparative analysis of six countries. Digit. J. 2016, 5, 1173-1191. [CrossRef]

40. Zephr. Bundling vs. Unbundling Digital Subscriptions. What Publishers Should Choose to Drive Growth. 2021. Available online: https:/ / www.zephr.com/hubfs/whitepaper/Bundling_vs_Unbundling_Digital_Subscriptions.pdf (accessed on 16 July 2021).

41. Tipser. The State of Content and Commerce. Media Trends Report. 2021. Available online: https://www.inma.org/report-detail. cfm?pubid=216 (accessed on 16 July 2021).

42. Berger, B. Commerce-oriented revenue models for content providers: An experimental study of commerciality's effect on credibility. Electron. Mark. 2018, 28, 93-109. [CrossRef]

43. Ladson, N.; Lee, A.M. Persuading to pay: Exploring the what and why in crowdfunded journalism. Int. J. Media Manag. 2017, 19, 144-163. [CrossRef]

44. Carvajal, M.; García-Avilés, J.A.; Gonzalez, J.L. Crowdfunding and non-profit media: The emergence of new models for public interest journalism. J. Pract. 2012, 6, 638-647. [CrossRef] 
45. Harlow, S. Entrepreneurial news sites as worthy causes? Exploring readers' motivations behind donating to Latin American journalism. Digit. J. 2021, 9, 364-383. [CrossRef]

46. Gomez-Diago, G. Communication in Crowdfunding Platforms. In Creativity in the Digital Age; Zagalo, E., Branco, P., Eds.; Springer: London, UK, 2015; pp. 171-190.

47. Nielsen, R.; Linnebank, G. Public Support for the Media: A Six-Country Overview of Direct and Indirect Subsidies; Reuters Institute for the Study of Journalism: Oxford, UK, 2011.

48. Dragomir, M. Control the money, control the media: How government uses funding to keep media in line. Journalism 2018, 19, 1131-1148. [CrossRef]

49. Nunes, A.C.B.; Canavilhas, J. Journalism Innovation and Its Influences in the Future of News: A European Perspective Around Google DNI Fund Initiatives; Springer: Cham, Switzerland, 2020; pp. 41-56. [CrossRef]

50. Noguera-Vivo, J.-M. Panorámica de la convergencia periodística: Los caminos hacia la redacción Google. Prof. Inf. 2010, 19, 652-657. [CrossRef]

51. Salaverría, R.; Martínez-Costa, M.D.P.; Breiner, J.G.; Bruna, S.N.; Rey, M.C.N.; Jimeno, M. Capítulo 1. El mapa de los cibermedios en España. Espejo De Monogr. De Comun. Soc. 2021. [CrossRef]

52. Tejedor, S.; Pablos, A.P. Análisis del modelo de ingresos en medios nativos digitales de carácter alternativo de España. Rev. Comun. 2020, 19, 275-295. [CrossRef]

53. Barranquero, A.; Sánchez Moncada, M. Cooperativas de medios en España. Un periodismo emprendedor y ciudadano en tiempos de crisis. Rev. Estud. Coop. 2018, 128, 36-58. [CrossRef]

54. Negreira-Rey, M.-C.; López-García, X.; Vázquez-Herrero, J. Mapa y características de los cibermedios locales e hiperlocales en España. Rev. Comun. 2020, 19, 193-214. [CrossRef]

55. Negreira-Rey, M.-C.; López-García, X.; Rodríguez-Vázquez, A.I. Los cibermedios locales e hiperlocales en España y Portugal. Sur J. 2018, 7, 50-63. Available online: http://www.surlejournalisme.kinghost.net/ojs3/index.php/slj/article/view/358 (accessed on 10 August 2021).

56. Nicholls, T.; Shabbir, N.; Nielsen, R.K. Digital Born News Media in Europe; Reuters Institute for the Study of Journalism: Oxford, UK, 2016.

57. McDowell, W.S. The brand management crisis facing the business of journalism. Int. J. Media Manag. 2011, 13, 37-51. [CrossRef]

58. Arrese, A.; Kaufmann, J. Legacy and native news brands online: Do they show different news consumption patterns? Int. J. Media Manag. 2016, 18, 75-97. [CrossRef]

59. Vara-Miguel, A. Cross-national similarities and differences between legacy and digital-born news media audiences. Media Commun. 2020, 8, 16-27. [CrossRef]

60. Siegert, G.; Förster, K.; Chan-Olmsted, S.M.; Ots, M. Handbook of Media Branding; Springer: Cham, Switzerland, 2005.

61. Asociación de la Prensa de Madrid. Informe Anual de la Profesión Periodística 2017; Asociación de la Prensa de Madrid: Madrid, Spain, 2017. Available online: https:/ / www.apmadrid.es/wp-content/uploads/2018/10/APM-Informe-2017_baja.pdf (accessed on 10 August 2021).

62. Hess, K.; Waller, L. Community and hyperlocal journalism. A sustainable model. In The Routledge Companion to Digital Journalism Studies; Franklin, B., Elridge, S.A., Eds.; Routledge: New York, NY, USA, 2017; pp. 194-203.

63. Abernathy, P. Saving Community Journalism. The Path to Profitability; University of North Carolina Press: Chapel Hill, NC, USA, 2014.

64. Goyanes, M. The value of proximity: Examining the willingness to pay for online local news. Int. J. Commun. 2015, 9, 1505-1522.

65. Myllylahti, M. What content is worth locking behind a paywall? Digit. J. 2017, 5, 460-471. [CrossRef]

66. Salaverría, R.; Martínez-Costa, M.P.; Breiner, J. Mapa de los cibermedios de España en 2018: Análisis cuantitativo. Rev. Lat. Comun. Soc. 2018, 73, 1034-1053. Available online: http://www.revistalatinacs.org/073paper/1295/54es.html (accessed on 10 August 2021).

67. Negredo, S.; Martínez-Costa, M.P.; Breiner, J.; Salaverría, R. Journalism expands in spite of the crisis: Digital-native news media in Spain 2020. Media Commun. 2021, 8, 73-85. [CrossRef]

68. Salaverría, R.; Martínez-Costa, M.P.; Breiner, J.G.; Negredo Bruna, S.; Negreira Rey, M.C.; Jimeno, M.A. El mapa de los cibermedios en España. In Ecosistema de los Cibermedios en España: Tipologías, Iniciativas, Tendencias Narrativas y Desafios; Toural-Bran, C., López-García, X., Eds.; Comunicación Social: Salamanca, Spain, 2019; pp. 25-49.

69. Negredo, S.; Martínez-Costa, M.P. Tipos de medios nativos digitales: Plataformas, alcance geográfico, lenguas y grupos empresariales. In Medios Nativos Digitales en España: Caracterización y Tendencias; Salaverría, R., Martínez-Costa, M.P., Eds.; Comunicación Social: Salamanca, Spain, 2021.

70. Abraira, V. El índice kappa. Semer.-Med. Fam. 2000, 27, 247-249. [CrossRef]

71. Stockemer, D. Quantitative Methods for the Social Sciences; Springer: Cham, Switzerland, 2019.

72. Salaverría, R. Periodismo digital: 25 años de investigación. Artículo de revisión. Prof. Inf. 2019, 28, 1-27. [CrossRef]

73. Casero-Ripollés, A.; Izquierdo-Castillo, J. Between decline and a new online business model: The case of Spanish newspaper industry. J. Media Bus. Stud. 2013, 10, 63-78. [CrossRef]

74. Carvajal-Prieto, M.; Valero-Pastor, J.M. Revenue streams within Spain's journalism industry, according to its editors. Hipertext. Net 2018, 17, 83-94.

75. Picard, R.G. State aid for news: Why subsidies? Why now? What kinds. In State Aid for Newspapers: Theories, Cases, Actions; Murshchetz, P., Ed.; Springer: Berlin, Germany, 2013; pp. 49-57. 